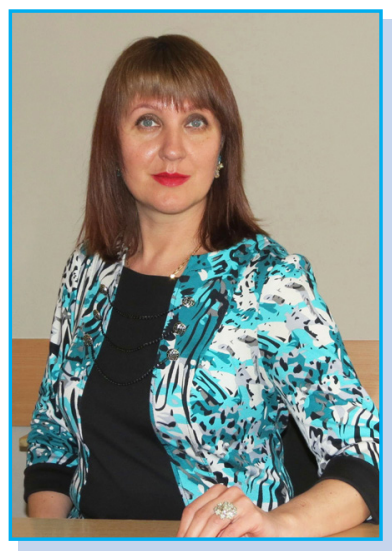

Інна Варнавська - кандидат педагогічних наук, доцент, в.о. завідувача кафедри професійної освіти Херсонського державного аграрно-економічного університету, м.Херсон, Україна

Коло наукових інтересів: дослідження теоретичних і практичних проблем навчання української мови в закладах вищої освіти; специфіка формування мовленнєвої компетентності студентів-аграрників; зміст курсу «Українська мова (за професійним спрямуанням)» та принципи добору фахових текстів. Наукова школа М.І.Пентилюк «Актуальні проблеми сучасної української лінгводидактики».

vav2005@gmail.com

https://orcid.org/0000-0002-3061-0665

УДК 378.81:330

https://doi.org/10.32405/2411-1317-2021-3-116-122

\title{
ПРОБЛЕМИ ФОРМУВАННЯ КОМУНІКАТИВНОÏ КОМПЕТЕНТНОСТІ ЗДОБУВАЧІВ ЕКОНОМІЧНИХ СПЕЦІАЛЬНОСТЕЙ
}

У статті теоретично обгрунтовано необхідність формування комунікативної компетентності як важливої складової професійної компетентності майбутніх фахівців економічного напряму. Проаналізовано такі базові складові компетентностей здобувачів вищої освіти: лінгвістична (мовна), соціолінгвістична, соціокультурна, дискурсивна, стратегічна і соціальна. Зазначено, що вивчення дисципліни «Українська мова (за професійним спрямуванням)» покликане забезпечити формування загальнокультурної компетентності. Наведено приклади завдань, які сприяють формуванню умінь працювати з текстами документів, правильно використовувати систему мовних норм і вибирати комунікативну поведінку відповідно до цілей і ситуацією спілкування у межах професійної сфери діяльності.

Ключові слова: студенти економічних спеціальностей; комунікативна компетентність; освітня діяльність; сучасні фахівці в галузі економіки, українська мова за професійним спрямуванням.

Постановка проблеми. Істотним показником освіченості та інтелектуального розвитку сучасних фахівців, особливо тих, які працюють у галузі економіки, є здатність застосовувати знання сучасної української літературної мови у своїй професійній діяльності. Коли акцентують увагу на професійній компетентності спеціаліста, то йдеться передусім про його знання відповідного спрямування - економічної підготовки, але водночас не треба ігнорувати професійних знань, які підкріплені загальною гуманітарною культурою людини, її вміннями орієнтуватися в навколишньому світі, здатністю спілкуватися.

«Професійна компетентність є значущим фактором, що дозволяє випускнику адекватно інтегруватися в соціальний простір i, займаючись певного роду діяльністю, спрямувати свій вплив на навколишнє природне, соціальне середовище і різні суспільні відносини» [1].

Аспекти цієї проблеми почали активно нами досліджуватися після проведеного тестування 3 дисципліни «Українська мова (за професійним спрямуванням)» у грудні 2019 року серед контингенту студентів першого курсу економічного факультету Херсонського державного аграрноекономічного університету. Дані тестування представлені в таблиці 1. 
Таблиця 1

\begin{tabular}{|c|l|c|c|c|}
\hline \multicolumn{1}{|c|}{$\begin{array}{c}\text { № } \\
\text { п/п }\end{array}$} & \multicolumn{1}{|c|}{$\begin{array}{c}\text { Нпзва } \\
\text { спецьальнсті (спрямування) }\end{array}$} & $\begin{array}{c}\text { Контингент } \\
\text { здобувачів, } \\
\text { які проходили } \\
\text { тестування }\end{array}$ & $\begin{array}{c}\text { Контингент } \\
\text { здобувачів, } \\
\text { які набрали } \\
\mathbf{7 4 - 1 0 0 ~ б а л і в ~}\end{array}$ & $\begin{array}{c}\text { Відсоток } \\
\text { засвосння } \\
\text { навчального } \\
\text { матеріалу }\end{array}$ \\
\hline 1 & 051 Економіка & 24 & 17 & 71 \\
\hline 2 & 071 Облік і оподаткування & 17 & 12 & 71 \\
\hline 3 & 073 Менеджмент & 32 & 25 & 78 \\
\hline 4 & 076 Підприємництво, торгівля та біржова діяльність & 24 & 16 & 67 \\
\hline 5 & 241 Готельно-ресторанна справа & 38 & 33 & 89 \\
\hline 6 & 281 Публічне управління та адміністрування & 19 & 13 & 68 \\
\hline
\end{tabular}

Аналіз останніх досліджень і публікацій з проблеми. Компетентнісний підхід, зокрема комунікативної компетентності, як проблема формування особистості фахівця була предметом дослідження як вітчизняних (Н. Бутенко, О. Брюховецька, О. Горошкіна, М. Лукашевич, М. Пентилюк та інші), так і зарубіжних (Г. Баловська, А. Главачек, В. Кан-Калик, Ю. Крижанська, Л. Петровська, В. Шейнов та інші) дослідників. Науковці зазначають, що комунікативна компетентність вимагає певної сформованості знань, навичок і вмінь, які формуються у процесі спеціально організованого навчання.

Так, Б. Біляєв розумів комунікативу компетентність як здатність встановлювати і підтримувати необхідні контакти з іншими людьми, як певну сукупність знань, умінь і навичок, що забезпечують ефективне спілкування [2]. Як зазначав дослідник, ця компетентність враховує уміння змінювати коло спілкування, розуміти співрозмовника і бути зрозумілим для нього.

Комунікативна компетентність, на думку Н. Чепелєвої, формується в умовах безпосередньої взаємодії, тому є результатом досвіду спілкування між людьми. А найважливіше, цей досвід набувається не тільки у процесі безпосередньої взаємодії, а найчастіше опосередковано, особливо через читання літератури, відвідування театру, кіно, де людина отримує інформацію про характер комунікативних ситуацій, особливості міжособистісної взаємодії і засоби їх вирішень. У процесі опанування комунікативною сферою особистість запозичає з культурного середовища засоби аналізу комунікативних ситуацій у вигляді словесних і візуальних форм [3].

На думку А. Богуш, під комунікативною компетентністю слід розуміти «комплексне застосування мовцем мовних і немовних засобів з метою спілкування в конкретних соціальнопобутових ситуаціях, уміння орієнтуватися в ситуації спілкування, ініціативність спілкування ... комунікативна компетенція - це обізнаність людини, певна система знань, практичних мовленнєвих умінь і навичок, мовленнєвих здібностей людини» [4].

Формування цілей статті. Мета наукового дослідження полягає у теоретичному та практичному обгрунтуванні необхідності формування комунікативної компетентності як важливої складової професійної компетентності майбутніх спеціалістів економічного напряму.

Виклад основного матеріалу. Комунікативна компетентність є однією з професійних компетентностей фахівців. Вважаємо за необхідне виокримити кілька ії складників: лінгвістична (мовна), соціолінгвістична (уміння використовувати мовний матеріал відповідно до контексту), соціокультурна (уміння користуватися знаннями історії, культури, традицій і звичаїв країни, мова якої досліджується), дискурсивна (уміння організувати мовлення, підтримати розмову, слухати співрозмовника, враховувати його точку зору), стратегічна (уміння ставити завдання, досягати мети, встановлювати контакт із співрозмовником) і соціальна (уміння поставити себе на місце іншого і здатність впоратися з ситуацією).

В основу формування комунікативної компетентності у здобувачів з дисциплін гуманітарного циклу закладено компетентнісний підхід, який розвиває самостійну творчу активність кожно- 
го студента. Навчання передбачає на початковому етапі (першому курсі) спільну освітню діяльність під керівництвом педагога, а потім самостійну.

Розвиток комунікативної компетентності - процес тривалий і досить складний. Особливу складність у викладанні гуманітарних дисциплін надає співвідношення предметного курсу і реального мовного досвіду студентів, процес здобування знань про культуру і процес оволодіння мовою.

Вивчення дисципліни «Українська мова (за професійним спрямуванням)» покликане забезпечити формування універсальної (загальнокультурної) компетенції: правильно, аргументовано і чітко будувати усне і писемне мовлення, здатність вільно володіти сучасною літературною українською літературною. навичками публічного і наукового мовлення; створювати і редагувати тексти професійного спрямування, аналізувати логіку міркувань і висловлювань. На вивчення дисципліни відводиться один семестр (1-й семестр 1 курсу), інших лінгвістичних дисципліни (окрім іноземної мови) студенти не вивчають. Одним із контрольних заходів є проходження тестування на веб-середовищі Moodle. Варто закцентувати: середній показник результатів тестування здобувачів економічних спеціальностей потребує додаткового опрацювання, тому вважаємо, що необхідна особлива професійна орієнтованість змісту тестів.

Політична, соціально-економічна ситуація, яка назаразі існує, вимагає від майбутнього фахівця швидкої реакції на зміни, які відбуваються, і здатності до гнучкої адаптації у професійній сфері діяльності. Адже керівники підприємств зіштовхуються із проблемою неефективності діяльності нових співробітників. Однією із причин цього часто $є$ несформованість у молодого фахівця комунікативної компетентності.

Володіння комунікативною компетентністю необхідно фахівцям економічної сфери діяльності, адже вона пов'язана зі встановленням контактів, спілкуванням в соціумі, роботою із потоками інформації. «Для людей у бізнесі пріоритетним $є$ вміння зрозуміти і передати інформацію. Необхідні вміння і навички включають впевненість і швидкість мовлення, вміння організувати і структурувати інформацію, достатня граматична компетенція...» [5].

Як показують соціально-психологічні дослідження, сучасні випускники-економісти зазнають серйозних труднощів у сфері професійного спілкування з колегами і клієнтами, та у веденні ділової переписки. Уміння вести ділову документацію та ділове листування, особливо у період дистаційної фороми спілкування, дуже важливе для ведення бізнесу і комерційної діяльності.

Формування умінь працювати з текстами документів - одне з найактуальніших завдань під час навчання здобувачів економічних напрямів, оскільки затребуваність фахівців у цій сфері, їх конкурентоспроможність значною мірою залежать від грамотної мови (усної і письмової). Відтак пропонуємо першокурсникам виконання подібних завдань:

Укладіть заяву, дотримуючись вимог до їі оформлення. Виправте мовні помилки у тексті.

Директору МКП «Херсонелектротрансу» панові Житченко Ігорю Владимировичу

Кузьменко Віктора Олексієвича, що проживає по адресі: 73036, Херсон-73036,Перекопська вул. 169, кв. 17 тел. 099-618-99-57

заява.

Я прошу прийняти Вас мене на роботу до МКП «Херсонелектротрансу» на посаду бухгалтера.

Додаток:

1) копія диплому про вищу освіту на 1 а. в 1 екз.

2) трудова книжка

3) особистий листочок з обліка кадрів на 3 а. в 1 екз.

Кузьменко

03.07.21 


\section{Відредагуйте речення. Проаналізуте правильні фрагменти документів}

1. Декану НПУ ім. М.П. Драгоманова доц. Варавенко Семену Миколайовичу студента 13 е/ю групи економічного факультету Гнатенко Бориса Олексійовича;

2. Я, Костенко А.А., народився 1.12.2004 року;

3. Прошу прийняти мене на посаду менеджера по рекламі з 15.VI.2021 р. із випробувальним строком 1 місяць.

Навчання професійному спілкуванню має бути спрямоване на формування комунікативної компетентності, яка означає здатність здійснювати мовну діяльність засобами української літературної мови, правильно використовувати систему мовних норм і вибирати комунікативну поведінку відповідно до цілей і ситуацій спілкування у межах професійної сфери діяльності. Так, на заняттях з теми «Морфологічні особливості професійного мовлення» доречними будуть завдання:

\section{Запишіть подані іменники в родовому відмінку однини. Поясніть закінчення.}

Ваучера, ринок, вексель, дебет, економіст, документ, папір, термін, формуляр, експорт, супермаркет, підпис, департамент, заклад, ксерокс, апарат, адресант, бланк, банк, комп'ютер, університету, адрес, курс, колектив, виробіток, спеціаліст, приріст, здобувач, відмінок, термінал, стиль.

Укладіть словник із 15 термінів (іменників II відміни чоловічого роду) відповідно до економічного напряму. До кожної словникової статті додайте самостійно складене речення з формою родового відмінка описаного слова.

\section{Зразок:}

Експорт (лат. ехроrto - «вивезення із порту») - продаж товарів або послуг в інші країни.

Приклади: Багато експертів економічного напряму занепокоєнні масштабами експорту зернових культур із нашої країни.

На практичних заняттях з теми «Синтаксичні особливості професіійного мовлення» пропонуємо здобувачам виконати подібні завдання:

\section{Відредагуйте речення, де порушено порядок слів.}

1. Наведені в цьому розділі, типові форми документів використовуватися можуть для укладання науково-технічної продукції. 2. За цим договором несе відповідальність за неналежне використання обов'язків орендар. 3. Через свого представника з числа співавторів ознайомитися з усіма матеріалами мають право автори. 4. Сторони за взаємною згодою достроково мають право розірвати договір. 5. Під час перебування делегації з офіційним візитом неофіційні зустрічі організовують також. 6. За взаємною домовленістю визначається місце і час проведення дебатів. 7. Якщо цього не вимагає ситуація, службові листи не повинні бути надто довгими.

Відсутність у змісті навчання матеріалів із галузі культури, політики, економіки (як, утім, i їх безсистемне або занадто широке використання на заняттях) істотно знижує не тільки загальну, але і професійну мотивацію навчання студентів-економістів. Визначивши основні компоненти змісту професійно і особистісно спрямованого навчання ділового мовлення здобувачів економічного профілю, перейдемо до відбору і організації навчального матеріалу. Професійна спрямованість змісту навчання мовлення реалізується через відбір конкретного мовного матеріалу з урахуванням особливостей майбутньої професії. Проблема добору та організації навчального матеріалу доволі складна. Підходи до вирішення цієї проблеми різноаспектні. Поряд із традиційними формами навчання професійного, ділового мовлення існують різні критерії добору й організації навчального матеріалу. Лексику варто добирати відповідно до критерію частотності, тобто таку, яка найбільш часто трапляється в економіч- 
ній сфері спілкування. Якщо матеріал не має безпосереднього практичного значення, то ефективність його засвоєння знижується, а, отже, знижується і рівень сформованості професійної компетентності.

Із вищевикладеного можна зробити висновок, що необхідно істотно переглянути змістовий складник робочої програми з дисципліни «Українська мова (за професійним спрямуванням)» для економічних спеціальностей (напрямів), що реалізуються у ЗВО, а також якісно змінити склад завдань, які наповнюють тестові завдання, спираючись на професійну орієнтацію.

Також для студентів економічних (і не тільки) спеціальностей внесені у список науководослідних тем з дисципліни «Українська мова (за професійним спрямуванням)» такі аспекти: «Вплив соціальних мереж на мовну культуру сучасної молоді», «Мовна компетенція сучасного економіста (менеджера)», «Історія Херсона» (або будь-якого іншого міста Херсонської областей) у його назвах. Для того, щоб оцінити ступінь зацікавленості цією тематикою, студентам першого курсу напряму «Підприємництво, торгівля та біржова діяльність» було запропоновано участь у дослідженні з теми «Що впливає на мою мовну культуру?». Адже теоретичну базу змісту навчання професійного мовлення становлять дані не тільки лінгвістики, а й психології і педагогіки, які пов’язуються з віковими характеристиками. Завдання під час навчання повинні бути спрямовані на максимальне розкриття тих можливостей здобувачів вищої освіти, які характерні для їхнього віку» [6]. Перше місце (75\%) - спілкування в соціальних мережах; друге місце (18\%) - 3МІ; третє місце (7\%) - не достатній рівень викладання української мови і літератури в загальноосвітніх навчальних закладах.

Відповіді студентів засвідчують, що у цій групі була представлена до розроблення така тема для науково-дослідної роботи: «Вплив соціальних мереж на мовну культуру сучасної молоді». Результати перевершили очікування. Здобувачі, які раніше уникали публічно висловлювати свою точку зору через низку причин, тому що «Не мають в активі навіть мінімальних стандартів мовної культури, не вміють зв’язно викладати думки в усній і письмовій формі, не усвідомлюють взаємозв’язок літературних норм і реалізації мовних засобів у різних типах мовлення» [7], почали говорити, сперечатися, доводити свої думки. Аргументація змушувала їх аналізувати мовний матеріал, проводити анкетування, диференціювати порушення норм сучасної української літературної мови, звертатися до словників і наукової літератури.

Висновки та перспективи подальших досліджень. Спираючись на наше дослідження, можна стверджувати, що більша частина помилок, що допускаються користувачами, на жаль, свідома, таким чином вони намагаються дотримуватися «етикету», який умовно прийнятий у соціальних мережах, зараховуючи себе до величезної армії покоління «online». Звідси випливає, що «мова соціальних мереж» - це невід’ємна частина сучасного молодіжного жаргону, тому можемо сміливо відзначити, що це явище тимчасове. Про сформованість комунікативної компетентності здобувачів економічного факультету Херсонського державного аграрноекономічного університету поки що ствержувати ще не можна, але зрушення на краще проглядаються однозначно. Активне застосування фахової термінології в усному і писемному мовленні, опрацювання текстів економічного спрямування, безсумнівно, дадуть позитивні результати, що дозволить підвищити рівень загальної професійної компетентності майбутнього економіста, менеджера, бухгалтера.

Формування і становлення комунікативної компетентності здобувачів позитивно впливає на професійний рівень майбутніх фахівців економічного напряму, їх творчу самореалізацію, удосконалення їх діяльності, особливо ці складові необіхдні для адекватної орієнтації в усіх сферах суспільного життя.

\section{Використані джерела}

[1] Н.П. Симаева, «Профессиональные компетенции студентов экономических и юридических специальностей: общее и особенное в содержании и условиях формирования», Вестник ВолГУ. Серия 6. Вып. 12, с. 50-58, 2010. 
[2] В.В. Богданов, «Коммуникативная компетенция и коммуникативное лидерство», Язык, дискурс и личность. Тверь, с. 26-31, 1990.

[3] Н.В. Чепелєва, «Становлення професійної компетентності в системі вузівської підготовки практичних психологів», Психолого-педагогічна наука і суспільна ідеологія: матеріали методологічного семінару АПН України, 12 листопада 1998 р. Київ, 1998.

[4] А.М. Богуш, «Становлення і розвиток української дошкільної лінгводидактики», Київ, 2019.

[5] О.Ю. Мельникова, «Обучение ведению деловой корреспонденции студентов экономических специальностей», Филологические науки. Методика преподавания языка и литературы. [Электронный ресурс]/ Доступно: http://www.rusnauka.com/12_ENXXI_2010/Philologia/65448.doc.htm/ Дата звернення: Травень 12, 2021.

[6] О.С. Преликова, «Проблемы профессиональной речевой подготовки студентов высших школ», Сборник научных трудов. Социально-экономические проблемы развития и процессы глобализации: потенциал возможного. СПб: Институт бизнеса и права, 2007 [Электронные ресурс]/ Режим доступа: http://www. ibl.ru/konf/061207/index.shtml/ Дата звернення: Травень 12, 2021.

[7] Т.С. Бочкарева, «Развитие речевой культуры студентов». Вестник ОГУ. Вып. 2. с. 58-62, 2001.

\section{References}

[1] N.P. Simaeva, «Professionalnyie kompetentsii studentov ekonomicheskih i yuridicheskih spetsialnostey: obschee i osobennoe v soderjanii i usloviyah formirovaniya», Vestnik VolGU. Seriya 6. Vyip. 12, s. 50-58, 2010. (in Russian).

[2] V.V. Bogdanov, «Kommunikativnaya kompetentsiya i kommunikativnoe liderstvo», YAzyik, diskurs ilichnost. Tver, s.26-31, 1990. (in Russian).

[3] N.V. Chepelyeva, «Stanovlennya profesijnoyi kompetentnosti v sy`stemi vuzivs`koyi pidgotovky` prakty`chny`x psy`xologiv», Psy`xologo-pedagogichna nauka i suspil`na ideologiya: materialy` metodologichnogo seminaru APN Ukrayiny`, 12 ly`stopada 1998 r. Ky`yiv, 1998. (in Ukrainian).

[4] A. M. Bogush, «Stanovlennya i rozvy`tok ukrayins`koyi doshkil`noyi lingvody`dakty`ky`», Ky`yiv, 2019. (in Ukrainian).

[5] O.YU. Melnikova, «Obuchenie vedeniyu delovoy korrespondentsii studentov ekonomicheskih spetsialnostey», Filologicheskie nauki. Metodika prepodavaniya yazyika i literaturyi. [Elektronnyiy resurs] / Dostupno: http://www.rusnauka.com/12_ENXXI_2010/Philologia/65448.doc.htm/ Data zvernennya: Traven 12, 2021. (in Russian).

[6] O.S. Prelikova, «Problemyi professionalnoy rechevoy podgotovki studentov vyisshih shkol», Sbornik nauchnyih trudov. Sotsialno-ekonomicheskie problemyi razvitiya i protsessyi globalizatsii: potentsial vozmojnogo. SPb: Institut biznesa i prava, 2007 [Elektronnyie resurs]/ Rejim dostupa: http://www.ibl.ru/konf/061207/index. shtml/ Data zvernennya: Traven 12, 2021. (in Russian).

[7] T.S. Bochkareva, «Razvitie rechevoy kulturyi studentov». Vestnik OGU. Vyip. 2. s. 58-62, 2001. (in Russian).

Inna Varnavskaya, PhD (Pedagogy), Associate Professor, Acting Head of the Department of Professional Education, Kherson State Agrarian and Economic University, Kherson, Ukraine.

\section{PROBLEMS OF THE FORMATION OF COMMUNICATIVE COMPETENCE OF APPLICANTS FOR ECONOMIC SPECIALTIES}

The article theoretically substantiates the need for the formation of communicative competence as an important component of professional competence of future specialists in economics. The basic components of modern human competencies are analyzed: linguistic (language), sociolinguistic, sociocultural, discursive, strategic and social. It is noted that the study of the discipline "Ukrainian language (for professional purposes)" is designed to ensure the formation of general cultural competence. The sociopsychological researches are considered, which prove that modern graduates-economists experience serious difficulties in the field of professional communication with colleagues and clients, conducting business correspondence. The ability to keep business records, especially during the distance form of 
communication is very important for doing business and maintaining business correspondence. Therefore, the formation of skills to work with the texts of documents is a more important task in training applicants for economic fields, as the demand for specialists in this field, their competitiveness depends largely on the availability of literate language (oral and written). For example, the tasks that contribute to the formation of skills to work with texts, documents, use the system of language norms and choose communicative behavior in accordance with the goals and situation of communication within the professional sphere. It is noted that the formation of communicative competence should not be said yet, but shifts in the right direction are taking place. After all, measures, which have been analyzed, will give positive results, which will increase the level of general professional competence of the future economist, manager, accountant. It is pointed out that the professional orientation of the content of speech training is realized through the selection of specific language material taking into account the peculiarities of the future profession. The problem of selection and organization of educational material is quite complex, and approaches to solving this problem are multifaceted. It is emphasized that along with the traditional forms of teaching professional, business speech, there are different criteria for selection and organization of educational material, and vocabulary should be selected in accordance with the criterion, in particular, the one most common in economic communication.

Key words: applicants for economic specialties; communicative competence; educational activities; modern specialists in the field of economics; Ukrainian literary language.

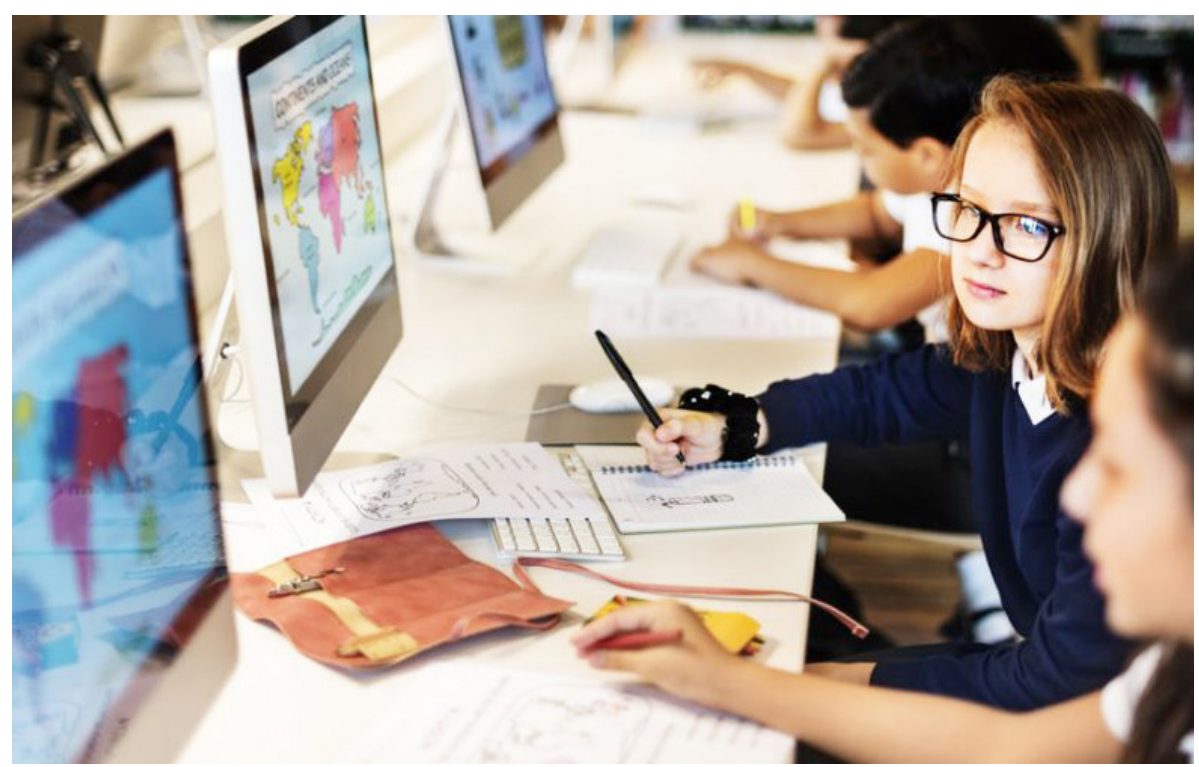

